\title{
Data report: radiolarian occurrences at IODP Expedition 329 Site U1371'
}

\author{
Giuseppe Cortese ${ }^{2}$ and Carlos A. Alvarez Zarikian ${ }^{3}$
}

\section{Chapter contents}

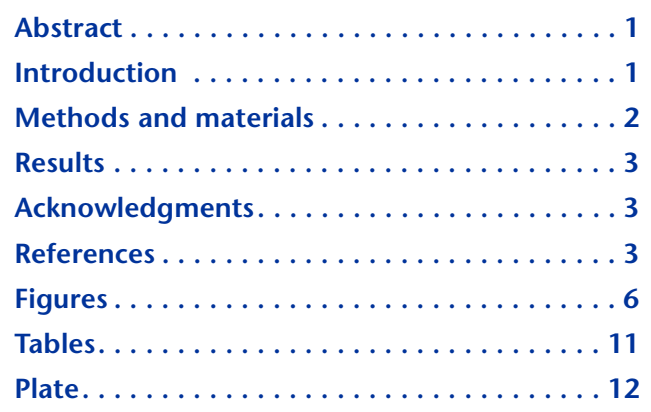

${ }^{1}$ Cortese, G., and Alvarez Zarikian, C.A., 2015. Data report: radiolarian occurrences at IODP Expedition 329 Site U1371. In D'Hondt, S., Inagaki, F., Alvarez Zarikian, C.A., and the Expedition 329 Scientists, Proc. IODP, 329: Tokyo (Integrated Ocean Drilling Program Management International, Inc.).

doi:10.2204/iodp.proc.329.202.2015

2GNS Science, PO Box 30 368, Lower Hutt 5040, New Zealand. g.cortese@gns.cri.nz

${ }^{3}$ International Ocean Discovery Program, Texas A\&M University, 1000 Discovery Drive, College Station TX 77845, USA.

\begin{abstract}
In this report we present a radiolarian biostratigraphy for the uppermost $108 \mathrm{~m}$ recovered during Expedition 329 at Integrated Ocean Drilling Program Site U1371.

This interval of clay-bearing diatom ooze contains well-preserved remains of siliceous microfossils. Below 108 meters below seafloor (mbsf), the sediment lithology changes to zeolitic clay, which does not contain any biosiliceous material.

Twenty-eight radiolarian marker species, used as age-indicative taxa in both middle- and high-latitude radiolarian biozonation schemes, have been recognized at this location and allow age control for the uppermost $\sim 100 \mathrm{~m}$ of the cored section, with an estimated age of $8.2 \mathrm{Ma}$ at $101.4 \mathrm{mbsf}$. These results match well those from a parallel study based on diatom biostratigraphy.
\end{abstract}

\section{Introduction}

Operations during Integrated Ocean Drilling Program (IODP) Expedition 329 (October-December 2010) drilled seven sites (U1365-U1371) spanning almost the entire width of the South Pacific Ocean (Fig. F1) and covering the full range of surfaceocean productivity conditions present in the South Pacific Gyre, ranging from extremely low productivity in the gyre center (Site U1368) to moderately high productivity at the southern edge of the gyre (Site U1371) (see the "Expedition 329 summary" chapter [Expedition 329 Scientists, 2011a]). This study reports on the semiquantitative radiolarian occurrences in 57 samples spanning the Neogene portion of the stratigraphic section recovered from Hole U1371D (Fig. F2; Plate P1) and provides a biostratigraphic record for Site U1371. This site was drilled southeast of Chatham Rise in the southwest Pacific at a water depth of $5301 \mathrm{~m}$. It is the only Expedition 329 site located in the upwelling zone just south of the gyre at the northern edge of the Antarctic Convergence. The stratigraphic section recovered in Hole U1371D comprises $\sim 108 \mathrm{~m}$ of clay-bearing diatom ooze overlying a $\sim 21 \mathrm{~m}$ thick sequence of pelagic clay (Fig. F3). The hole was cored to basement (see the "Site U1371" chapter [Expedition 329 Scientists, 2011c]). Based on a tectonic reconstruction of the region by Larson et al. (2002), the site lies on 73 Ma crust. The main aim of this study is to establish an age model for the sediment recovered at this site. 


\section{Methods and materials}

\section{Slide preparation}

Sediment samples ( $\sim 5 \mathrm{~g}$ dry weight) were placed in a beaker with $10 \% \mathrm{H}_{2} \mathrm{O}_{2}$ and disaggregated by warming on a hot plate for a few hours. Calcareous components were dissolved by adding a $10 \%$ solution of hydrochloric acid. The solution was then washed through a $40 \mu \mathrm{m}$ sieve. Strewn slides were prepared by pipetting the residue onto a microscope coverslip, which was then dried on a hot plate. Canada Balsam, applied to the coverslip, was used as a mounting medium. The coverslip was then inverted, placed on the slide, and indurated by placing the slide back on the hot plate for a few minutes.

\section{Radiolarian taxonomy and zonal schemes}

The main references for the taxonomy of radiolarians studied here were Nigrini and Lombari (1984), Sanfilippo et al. (1985), Lombari and Lazarus (1988), Lazarus (1990, 1992), Abelmann (1992), Nigrini and Sanfilippo (2001), Vigour and Lazarus (2002), and Nigrini et al. (2006). All radiolarian semiquantitative abundance data produced for this study are shown in Table T1.

Site U1371 is located at an intermediate latitude, and therefore the radiolarian biostratigraphic scheme developed for low/equatorial latitudes (Sanfilippo et al., 1985) as well as the age calibration of the key taxa used to establish such a zonation is not applicable, as most of the key taxa are not present.

Both high- and middle-latitude marker taxa have been recognized in this study, thus requiring the adoption of two different zonal schemes for their age interpretation and leading to two different age models for Hole U1371D. However, the two proposed age models do not differ substantially.

The middle-latitude radiolarian zonal scheme used here is the one described in Nigrini and Sanfilippo (2001), and its zonal definitions, and key marker species are shown in SMT1.XLS in RADIOLAR in "Supplementary material."

The high-latitude (Southern Ocean) radiolarian zones introduced by Lazarus (1990, 1992), Abelmann (1992), and Takemura (1992) were also applied to Hole U1371D samples. This composite zonation is shown in SMF1.JPG in RADIOLAR in "Supplementary material." The middle Miocene to Pleistocene zonation of Lazarus (1990) was refined by Lazarus (1992) using sediment recovered during Ocean Drilling Program Legs 119 and 120 (Kerguelen Plateau). The early to middle Miocene age zonation of Abel- mann (1992) is based on radiolarian studies from Leg 120. The studied sediment was not old enough to enable the recognition of any of the biozones defined in Takemura (1992).

Age estimates for radiolarian datums from the Quaternary to the Miocene (Table T2) are based on their calibration to magnetostratigraphy according to Hays and Opdyke (1967), Gersonde et al. (1990), Barron et al. (1991), Caulet (1991), Abelmann (1992), Lazarus (1992), Harwood et al. (1992), Shackleton et al. (1995), and Kamikuri et al. (2004).

The ages of biostratigraphically useful radiolarian datums from both the middle- and high-latitude zonations (Fig. F4) define the age model for Hole U1371D (Fig. F3).

\section{Microscope examination and radiolarian abundance conventions}

Radiolarian biostratigraphy was based on examination of the suite of samples listed in Table T1. Each slide was scanned throughout following traverses at $100 \times$ magnification.

The following conventions/abundance schemes were used for preservation, overall radiolarian abundance, and relative abundance of individual species.

Radiolarian preservation:

$\mathrm{G}=$ good (most specimens complete, minor dissolution, recrystallization, or breakage)

$\mathrm{M}=$ moderate (minor dissolution, some recrystallization or breakage)

$\mathrm{P}=$ poor (strong dissolution, recrystallization, or breakage)

$\mathrm{B}=$ barren (no radiolarians observed)

Overall radiolarian abundance:

$\mathrm{A}=$ abundant $(>100$ specimens per slide traverse)

$\mathrm{C}=$ common (51-100 specimens per slide traverse)

$\mathrm{F}=$ few (10-50 specimens per slide traverse)

$\mathrm{R}=$ rare $(<10$ specimens per slide traverse $)$

$\mathrm{B}=$ barren (no radiolarians in sample)

Abundance of individual species (relative to the total assemblage):

$\mathrm{A}=$ abundant $(>10 \%$ of the total assemblage or $>20$ per slide)

$\mathrm{C}=$ common $(5 \%-10 \%$ of the total assemblage or 11-20 per slide)

$\mathrm{F}=\mathrm{few}(<5 \%$ of the total assemblage or $5-10$ per slide)

$\mathrm{R}=$ rare (1-4 specimens per slide)

$\mathrm{X}=$ absent (looked for, but not observed in sample)

$\mathrm{Rw}=$ species presumably reworked 


\section{Results}

Semiquantitative relative abundance data for radiolarians have been produced for the uppermost $108 \mathrm{~m}$ of the sedimentary section drilled in Hole U1371D (Fig. F2; Table T1). Because of the geographic location of the drill site (Fig. F1) at the interface between subtropical and subantarctic surface water masses, the observed taxa comprise marker species present in both middle- (Nigrini and Sanfilippo, 2001) and high-latitude (Lazarus, 1990, 1992; Abelmann, 1992) radiolarian biozonation schemes (shown in SMF1.JPG and SMT1.XLS in RADIOLAR in "Supplementary material.")

The age calibration of the recognized bioevents has been performed in a series of previous studies (see the "Methods" chapter, [Expedition 329 Scientists, $2011 \mathrm{~b}]$ ), and it is reported, along with the occurrence of the events at Hole U1371D, in Table T2. This information has been used to derive a list of events (Fig. F4) that has allowed the establishment of two age models for Site U1371 (Fig. F3).

Although there are some slight differences between these two models, with the most obvious one occurring at $\sim 90.4$ mbsf (3.06 Ma according to middle-latitude markers or $4.6 \mathrm{Ma}$ according to high-latitude markers), the two models are in good agreement. Diatom biostratigraphy (see fig. F3 in Suto and Uramoto [in press]) provides an age of $\sim 7.25 \mathrm{Ma}$ at 90.4 mbsf (Fig. F5) based on interpolation between the two diatom events at $80 \mathrm{mbsf}$ (last appearance datum Hemidiscus triangularis; $6 \mathrm{Ma}$ ) and $100 \mathrm{mbsf}$ (first appearance datum Actinocyclus ingens var. ovalis; 8.67 $\mathrm{Ma})$. This result suggests that the high-latitude radiolarian zonation provides a better estimate of the actual age compared to its middle-latitude counterpart.

The general sedimentation history at this site seems to imply a relatively constant sediment accumulation rate (SR) downhole to 90.4 mbsf (mean SR = $29.5 \mathrm{~m} / \mathrm{m}$.y. when using the middle-latitude marker at this depth; mean $S R=19.7 \mathrm{~m} / \mathrm{m}$.y. when using the high-latitude marker instead), followed by a steep decrease downhole to 101.4 mbsf (mean SR $=2.14$ $\mathrm{m} / \mathrm{m}$.y. or mean $\mathrm{SR}=3.1 \mathrm{~m} / \mathrm{m}$.y., depending on the age assignment of the sample at $90.4 \mathrm{mbsf}$ ).

At 108 mbsf (top part of Core 329-U1371D-12H), a sharp lithologic boundary between clay-bearing diatom ooze (lithologic Unit I) and zeolitic pelagic clay (Unit II) suggests the presence of a transition, possibly through an unconformity, to much older, preMiocene material (see the "Site U1371" chapter [Expedition 329 Scientists, 2011c]) (Fig. F3). Based on the age model for the upper biosiliceous ooze section and the estimated crustal age at this location, the estimated sediment accumulation rate for the underlying pelagic clay section is $\sim 0.45 \mathrm{~m} / \mathrm{m}$.y.

The age interpretation of the radiolarian results presented here is also in good agreement (during the Pleistocene and the late to middle Miocene) with the diatom biostratigraphy from the same drilled section proposed by Suto and Uramoto (in press). The combined diatom, radiolarian, and paleomagnetic stratigraphies (Fig. F5), however, suggest how this agreement breaks down during the Pliocene. During this time, radiolarian markers are always younger than diatom and paleomagnetic events, with the high-latitude radiolarian zonation providing a better match to both diatom and paleomagnetic stratigraphies.

\section{Acknowledgments}

This research is based on samples and data provided by the Integrated Ocean Drilling Program (IODP). The authors acknowledge the support of IODP Expedition 329 chief scientists and scientific party, Annika Sanfilippo and Chris Hollis for discussion and comments on the data and manuscript, and the Global Change Through Time (GCT) Program at GNS Science for funding this study. We also thank Itsuki Suto for providing his summary figure for diatom, radiolarian, and paleomagnetic stratigraphies and for access to his diatom data; David Harwood for his comments and suggestions; and Sonja Fry for technical assistance in sample preparation.

\section{References}

Abelmann, A., 1992. Early to middle Miocene radiolarian stratigraphy of the Kerguelen Plateau, Leg 120. In Wise, S.W., Jr., Schlich, R., et al., Proceedings of the Ocean Drilling Program, Scientific Results, 120: College Station, TX (Ocean Drilling Program), 757-783. http://dx.doi.org/ 10.2973/odp.proc.sr.120.165.1992

Barron, J.A., Baldauf, J.G., Barrera, E., Caulet, J.-P., Huber, B.T., Keating, B.H., Lazarus, D., Sakai, H., Thierstein, H.R., and Wei, W., 1991. Biochronologic and magnetochronologic synthesis of Leg 119 sediments from the Kerguelen Plateau and Prydz Bay, Antarctica. In Barron, J., Larsen, B., et al., Proceedings of the Ocean Drilling Program, Scientific Results, 119: College Station, TX (Ocean Drilling Program), 813-847. http://dx.doi.org/

10.2973/odp.proc.sr.119.188.1991

Caulet, J.-P., 1991. Radiolarians from the Kerguelen Plateau, Leg 119. In Barron, J., Larsen, B., et al., Proceedings of the Ocean Drilling Program, Scientific Results, 119: College Station, TX (Ocean Drilling Program), 513-546. http://dx.doi.org/10.2973/odp.proc.sr.119.137.1991 
Cody, R.D., Levy, R.H., Harwood, D.M., and Sadler, P.M., 2008. Thinking outside the zone: high-resolution quantitative diatom biochronology for the Antarctic Neogene. Palaeogeography, Palaeoclimatology, Palaeoecology, 260(1-2):92-121. http://dx.doi.org/10.1016/ j.palaeo.2007.08.020

D'Hondt, S., Inagaki, F., Alvarez Zarikian, C.A., and the IODP Expedition 329 Science Party, 2013. IODP Expedition 329: life and habitability beneath the seafloor of the South Pacific Gyre. Scientific Drilling, 15:4-10. http:/ /dx.doi.org/10.2204/iodp.sd.15.01.2013

Expedition 329 Scientists, 2011a. Expedition 329 summary. In D'Hondt, S., Inagaki, F., Alvarez Zarikian, C.A., and the Expedition 329 Scientists, Proceedings of the Integrated Ocean Drilling Program, 329: Tokyo (Integrated Ocean Drilling Program Management International, Inc.). http://dx.doi.org/10.2204/ iodp.proc.329.109.2011

Expedition 329 Scientists, 2011b. Methods. In D'Hondt, S., Inagaki, F., Alvarez Zarikian, C.A., and the Expedition 329 Scientists, Proceedings of the Integrated Ocean Drilling Program, 329: Tokyo (Integrated Ocean Drilling Program Management International, Inc.). http://dx.doi.org/ 10.2204/iodp.proc.329.109.2011

Expedition 329 Scientists, 2011c. Site U1371. In D'Hondt, S., Inagaki, F., Alvarez Zarikian, C.A., and the Expedition 329 Scientists, Proceedings of the Integrated Ocean Drilling Program, 329: Tokyo (Integrated Ocean Drilling Program Management International, Inc.). http://dx.doi.org/ 10.2204/iodp.proc.329.109.2011

Gersonde, R., Abelmann, A., Burckle, L.H., Hamilton, N., Lazarus, D., McCartney, K., O'Brien, P., Spieß, V., and Wise, S.W., Jr., 1990. Biostratigraphic synthesis of Neogene siliceous microfossils from the Antarctic Ocean, ODP Leg 113 (Weddell Sea). In Barker, P.F., Kennett, J.P., et al., Proceedings of the Ocean Drilling Program, Scientific Results, 113: College Station, TX (Ocean Drilling Program), 915-936. http://dx.doi.org/10.2973/ odp.proc.sr.113.209.1990

Harwood, D.M., Lazarus, D.B., Abelmann, A., Aubry, M.-P., Berggren, W.A., Heider, F., Inokuchi, H., Maruyama, T., McCartney, K., Wei, W., and Wise, S.W., Jr., 1992. Neogene integrated magnetobiostratigraphy of the central Kerguelen Plateau, Leg 120. In Wise, S.W., Jr., Schlich, R., et al., Proceedings of the Ocean Drilling Program, Scientific Results, 120: College Station, TX (Ocean Drilling Program), 1031-1052. http://dx.doi.org/10.2973/ odp.proc.sr.120.185.1992

Hays, J.D., and Opdyke, N.D., 1967. Antarctic radiolaria, magnetic reversals, and climate change. Science, 158(3804):1001-1011. http://www.jstor.org.libezproxy.tamu.edu:2048/stable/1722956

Kamikuri, S., Nishi, H., Motoyama, I., and Saito, S., 2004. Middle Miocene to Pleistocene radiolarian biostratigraphy in the northwest Pacific Ocean, ODP Leg 186. Island Arc, 13(1):191-226. http://dx.doi.org/10.1111/ j.1440-1738.2003.00421.x

Larson, R.L., Pockalny, R.A., Viso, R.F., Erba, E., Abrams, L.J., Luyendyk, B.P., Stock, J.M., and Clayton, R.W.,
2002. Mid-Cretaceous tectonic evolution of the Tongareva triple junction in the southwestern Pacific Basin. Geology, 30(1):67-70. http://dx.doi.org/10.1130/00917613(2002)030<0067:MCTEOT>2.0.CO;2

Lazarus, D., 1990. Middle Miocene to Recent radiolarians from the Weddell Sea, Antarctica, ODP Leg 113. In Barker, P.F., Kennett, J.P., et al., Proceedings of the Ocean Drilling Program, Scientific Results, 113: College Station, TX (Ocean Drilling Program), 709-727. http:// dx.doi.org/10.2973/odp.proc.sr.113.132.1990

Lazarus, D., 1992. Antarctic Neogene radiolarians from the Kerguelen Plateau, Legs 119 and 120. In Wise, S.W., Jr., Schlich, R., et al., Proceedings of the Ocean Drilling Program, Scientific Results, 120: College Station, TX (Ocean Drilling Program), 785-809. http://dx.doi.org/ 10.2973/odp.proc.sr.120.192.1992

Lombari, G., and Lazarus, D.B., 1988. Neogene cycladophorid radiolarians from North Atlantic, Antarctic, and North Pacific deep-sea sediments. Micropaleontology, 34(2):97-135. http://dx.doi.org/10.2307/1485657

Nigrini, C., and Lombari, G., 1984. A Guide to Miocene Radiolaria. Special Publication-Cushman Foundation for Foraminiferal Research, 22.

Nigrini, C., and Sanfilippo, A., 2001. Cenozoic radiolarian stratigraphy for low and middle latitudes with descriptions of biomarkers and stratigraphically useful species. Ocean Drilling Program Technical Note, 27. http:// dx.doi.org/10.2973/odp.tn.27.2001

Nigrini, C., Sanfilippo, A., and Moore, T.C., Jr., 2006. Cenozoic radiolarian biostratigraphy: a magnetobiostratigraphic chronology of Cenozoic sequences from ODP Sites 1218, 1219, and 1220, equatorial Pacific. In Wilson, P.A., Lyle, M., and Firth, J.V. (Eds.), Proceedings of the Ocean Drilling Program, Scientific Results, 199: College Station, TX (Ocean Drilling Program), 1-76. http:// dx.doi.org/10.2973/odp.proc.sr.199.225.2006

Ogg, J.G., and Smith, A.G., 2004. The geomagnetic polarity time scale. In Gradstein, F., Ogg, J., and Smith, A. (Eds.), A Geologic Time Scale 2004: Cambridge, UK (Cambridge University. Press), 63-86. http://dx.doi.org/10.1017/ СBO9780511536045.006

Sanfilippo, A., Westberg-Smith, M.J., and Riedel, W.R., 1985. Cenozoic Radiolaria. In Bolli, H.M., Saunders, J.B., and Perch-Nielsen, K. (Eds.), Plankton Stratigraphy (Vol. 2): Radiolaria, Diatoms, Silicoflagellates, Dinoflagellates, and Ichthyoliths: Cambridge, UK (Cambridge Univ. Press), 631-712.

Shackleton, N.J., Baldauf, J.G., Flores, J.-A., Iwai, M., Moore, T.C., Jr., Raffi, I., and Vincent, E., 1995. Biostratigraphic summary for Leg 138. In Pisias, N.G., Mayer, L.A., Janecek, T.R., Palmer-Julson, A., and van Andel, T.H. (Eds.), Proceedings of the Ocean Drilling Program, Scientific Results, 138: College Station, TX (Ocean Drilling Program), 517-536. http://dx.doi.org/10.2973/ odp.proc.sr.138.127.1995

Suto, I., and Uramoto, G.-I., in press. Data report: diatom biostratigraphy of IODP Site U1371 in the South Pacific Ocean. In D'Hondt, S., Inagaki, F., Alvarez-Zarikian, C.A., and the Expedition 329 Scientists, Proceedings of 
the Integrated Ocean Drilling Program, 329: Tokyo (Integrated Ocean Drilling Program Management International, Inc.)

Takemura, A., 1992. Radiolarian Paleogene biostratigraphy in the southern Indian Ocean, Leg 120. In Wise, S.W., Jr., Schlich, R., et al., Proceedings of the Ocean Drilling Program, Scientific Results, 120: College Station, TX (Ocean Drilling Program), 735-756. http://dx.doi.org/ 10.2973/odp.proc.sr.120.177.1992

Vigour, R., and Lazarus, D., 2002. Biostratigraphy of late Miocene-early Pliocene radiolarians from ODP Leg 183
Site 1138. In Frey, F.A., Coffin, M.F., Wallace, P.J., and Quilty, P.G. (Eds.), Proceedings of the Ocean Drilling Program, Scientific Results, 183: College Station, TX (Ocean Drilling Program), 1-17. http://dx.doi.org/10.2973/ odp.proc.sr.183.007.2002

Initial receipt: 4 February 2014

Acceptance: 30 June 2015

Publication: 2 September 2015

MS 329-202 
Figure F1. Expedition 329 site location map. Site U1371 $\left(45^{\circ} 58^{\prime} \mathrm{S}, 163^{\circ} 11^{\prime} \mathrm{W}\right)$ is at the southern end of the southwestern transect and is the focus of this study.

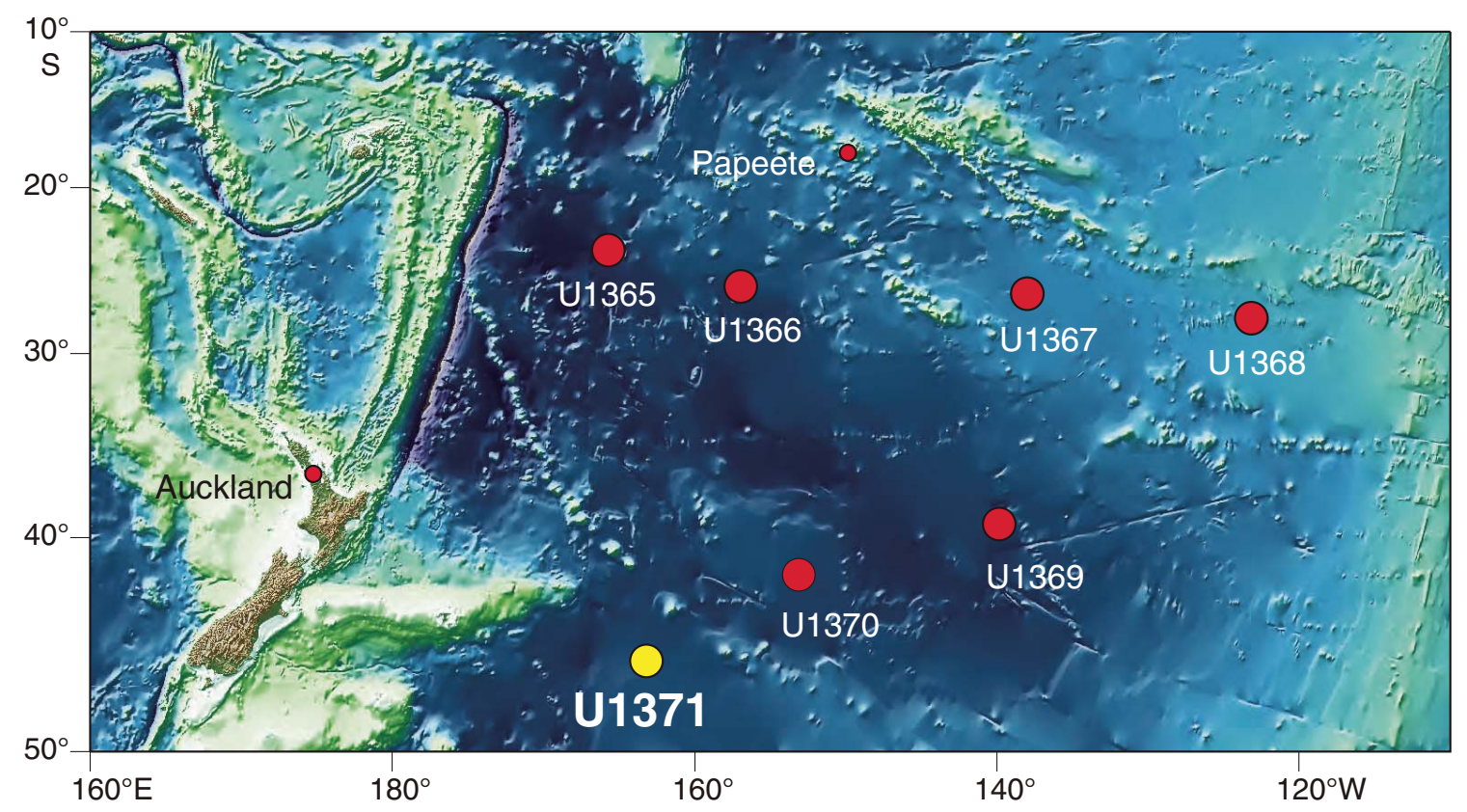


Figure F2. Radiolarian occurrences, Hole U1371D. Complete documentation of all radiolarian abundance counts is presented in Table T1. Red = species for middle-latitude zonation, TD = total depth.

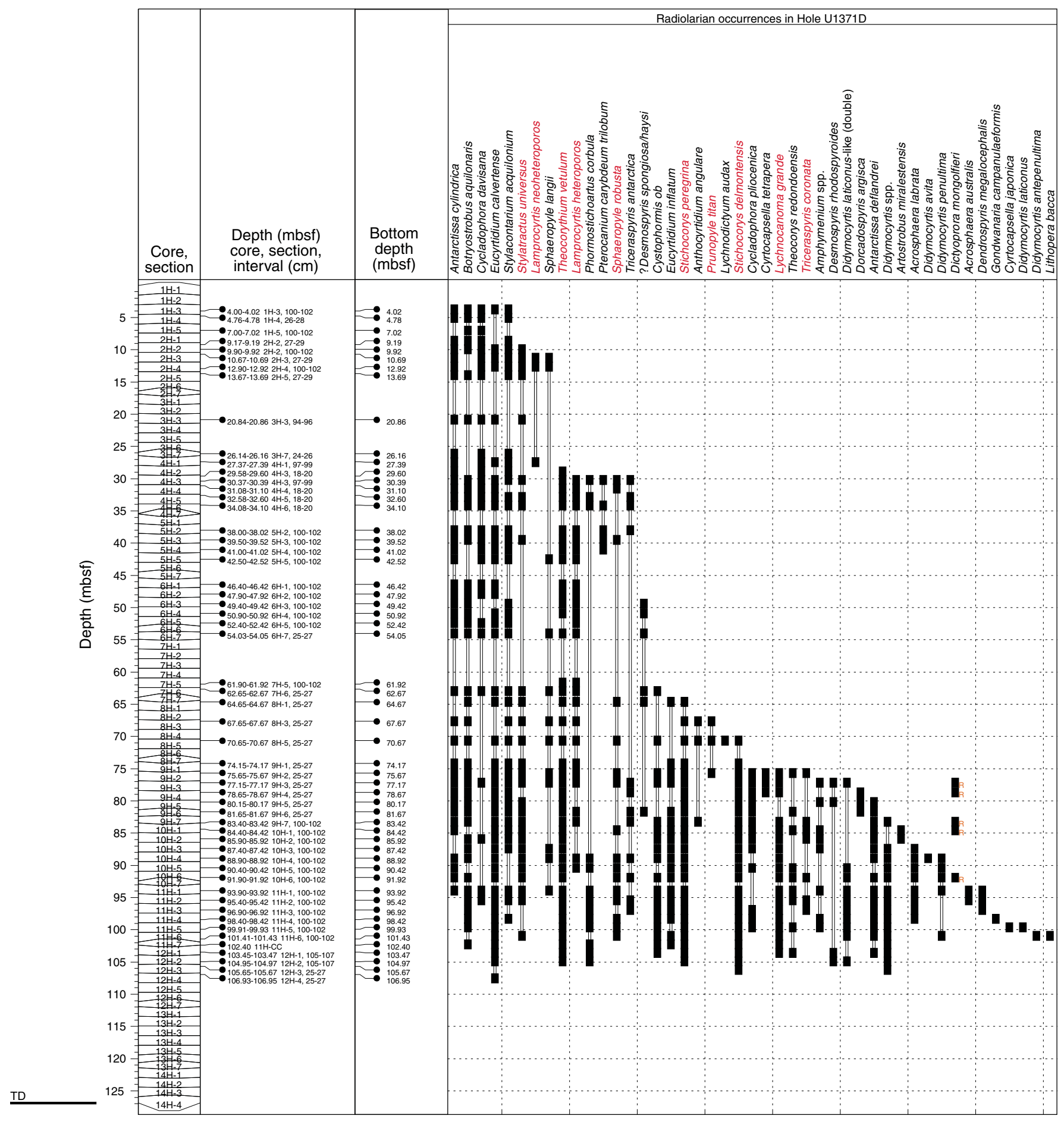


Figure F3. Downhole properties (see the "Site U1371" chapter [Expedition 329 Scientists, 2011c]) and interpreted age model of the selected radiolarian bioevents for both the middle- and high-latitude radiolarian zonations, Hole U1371D. Lithology: yellow = clay-bearing diatom ooze, brown = zeolitic pelagic clay. Crustal age from Larson et al. (2002).

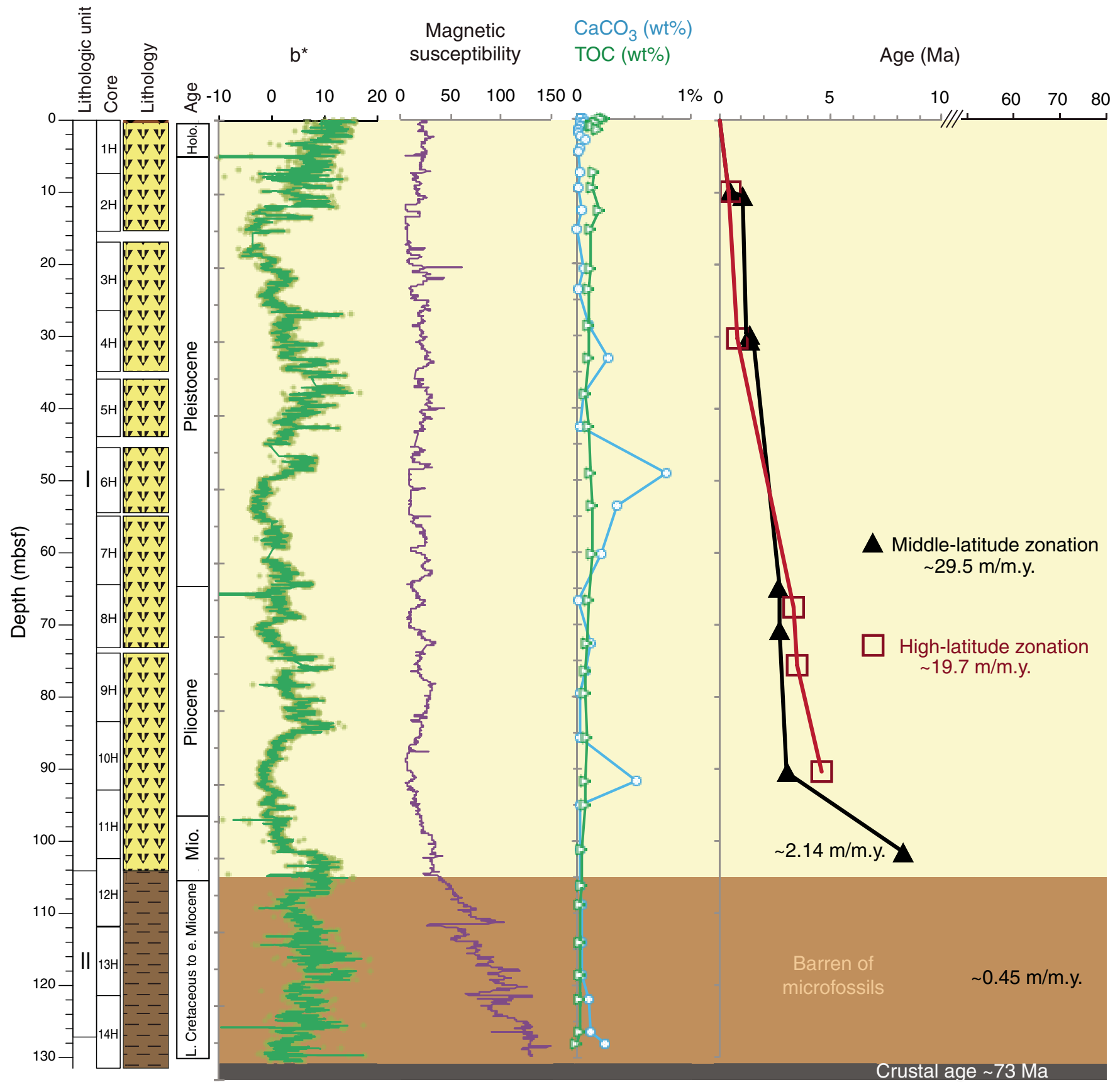


Figure F4. Radiolarian events used to develop an age model for Hole U1371D. Due to the presence of events typical for both the middle- and high-latitude radiolarian zonations, two alternative age interpretations are possible (Fig. F3). FAD = first appearance datum, $\mathrm{LAD}=$ last appearance datum, $\mathrm{LCO}=$ last common occurrence datum.

\begin{tabular}{|c|c|c|}
\hline \multicolumn{3}{|c|}{ Middle-latitude zonation } \\
\hline Depth (mbsf) & Age (Ma) & Event \\
\hline 0.00 & 0.00 & Top of core \\
\hline 9.90 & 0.43 & LAD Stylatractus universus \\
\hline 10.67 & 1.06 & LAD Lamprocyrtis neoheteroporos \\
\hline 29.58 & 1.22 & LAD Theocorythium vetulum \\
\hline 30.37 & 1.40 & LAD Sphaeropyle robusta \\
\hline 30.37 & 1.50 & LAD Lamprocyrtis heteroporos \\
\hline 64.65 & 2.70 & LAD Stichocorys peregrina \\
\hline 70.65 & 2.70 & LAD Stichocorys delmontensis \\
\hline 90.40 & 3.06 & FAD Lamprocyrtis heteroporos \\
\hline 101.4 & 8.2 & $\begin{array}{l}\text { Sphaeropyle langii, Didymocyrtis penultima, and } \\
\text { Didymocyrtis antepenultima (well calibrated } \\
\text { in the North Pacific but found with very few } \\
\text { specimens at Site U1371) }\end{array}$ \\
\hline \multicolumn{3}{|c|}{ High-latitude zonation } \\
\hline 0.00 & 0.00 & Top of core \\
\hline 9.90 & 0.43 & LAD Stylatractus universus \\
\hline 30.37 & 0.80 & LAD Pterocanium carybdeum trilobum \\
\hline 67.65 & 3.32 & LAD Prunopyle titan \\
\hline 75.65 & 3.50 & LAD Triceraspyris coronata \\
\hline 90.40 & 4.60 & LCO Lychnocanoma grande \\
\hline
\end{tabular}


Figure F5. Age-depth plot, Hole U1371D (slightly modified after fig. F3 in Suto and Uramoto [in press]). Ages of the diatom bioevents are from the mid-point of average range model of Cody et al. (2008). Polarity after the on-board results in the "Site U1371" chapter (Expedition 329 Scientists, 2011c). Chron boundary ages after the geomagnetic polarity timescale of Ogg and Smith (2004).

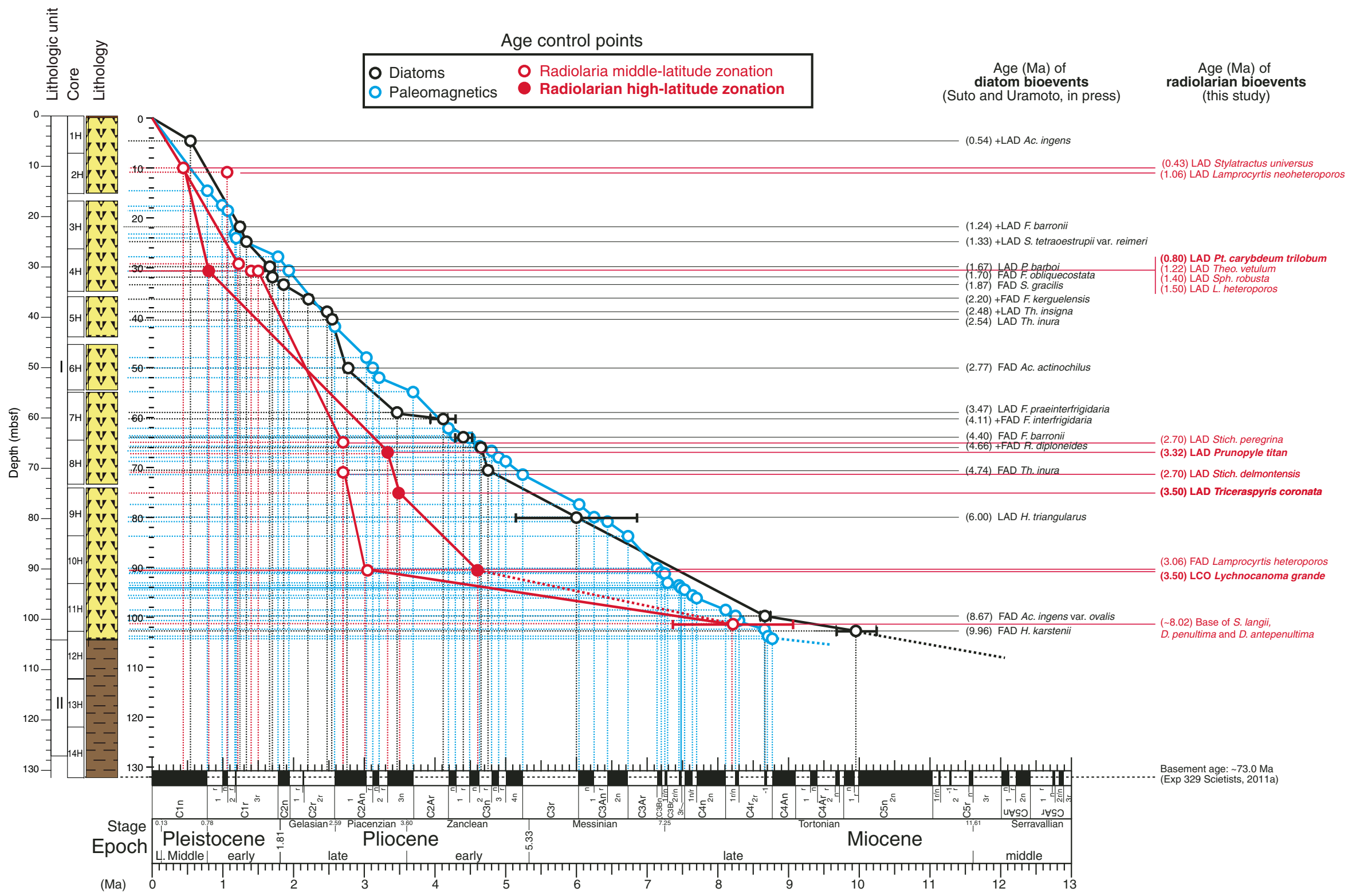


Table T1. Semiquantitative analysis of radiolarian abundances, Hole U1371D. This table is available in an oversized format.

Table T2. Minimum and maximum depth of occurrence for radiolarian marker species in Hole U1371D and age estimates for radiolarian datum events from both the middle- and high-latitude zonations. This table is available in an oversized format. 
Plate P1. Radiolarians, Hole U1371D. Scale bar $=50 \mu \mathrm{m}$. 1. Stylacontarium acquilonium. 2-4. Stylatractus universus. 5. Sphaeropyle robusta. 6. Lamprocyrtis neoheteroporos. 7, 8. Lamprocyrtis heteroporos. 9. Theocorythium vetulum. 10, 16. Stichocorys peregrina. 11. Stichocorys delmontensis. 12, 13. Sphaeropyle langii. 14. Didymocyrtis antepenultima. 15. Eucyrtidium calvertense. 17. Botryostrobus aquilonaris. (1-3) Sample 329-U1371D-8H-5, 25-27 cm; (4) Sample 329-U1371D-2H-5, 27-29 cm; (5, 8) Sample 329-U1371D-9H-3, 25-27 cm; (6) Sample 329U1371D-2H-4, 100-102 cm; (7, 9, 15, 17) Sample 329-U1371D-4H-6, 18-20 cm; (10, 14) Sample 329-U1371D11H-6, 100-102 cm; (11) Sample 329-U1371D-12H-2, 105-107 cm; (12): Sample 329-U1371D-11H-1, 100-102 cm; (13) Sample 329-U1371D-2H-3, 27-29 cm; (16) Sample 329-U1371D-8H-1, 25-27 cm. (Continued on next page.)
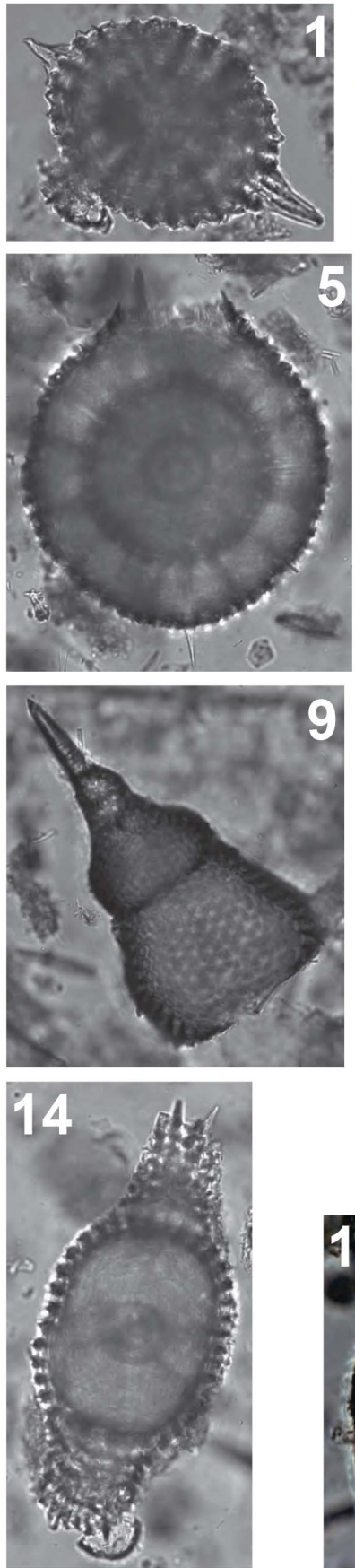
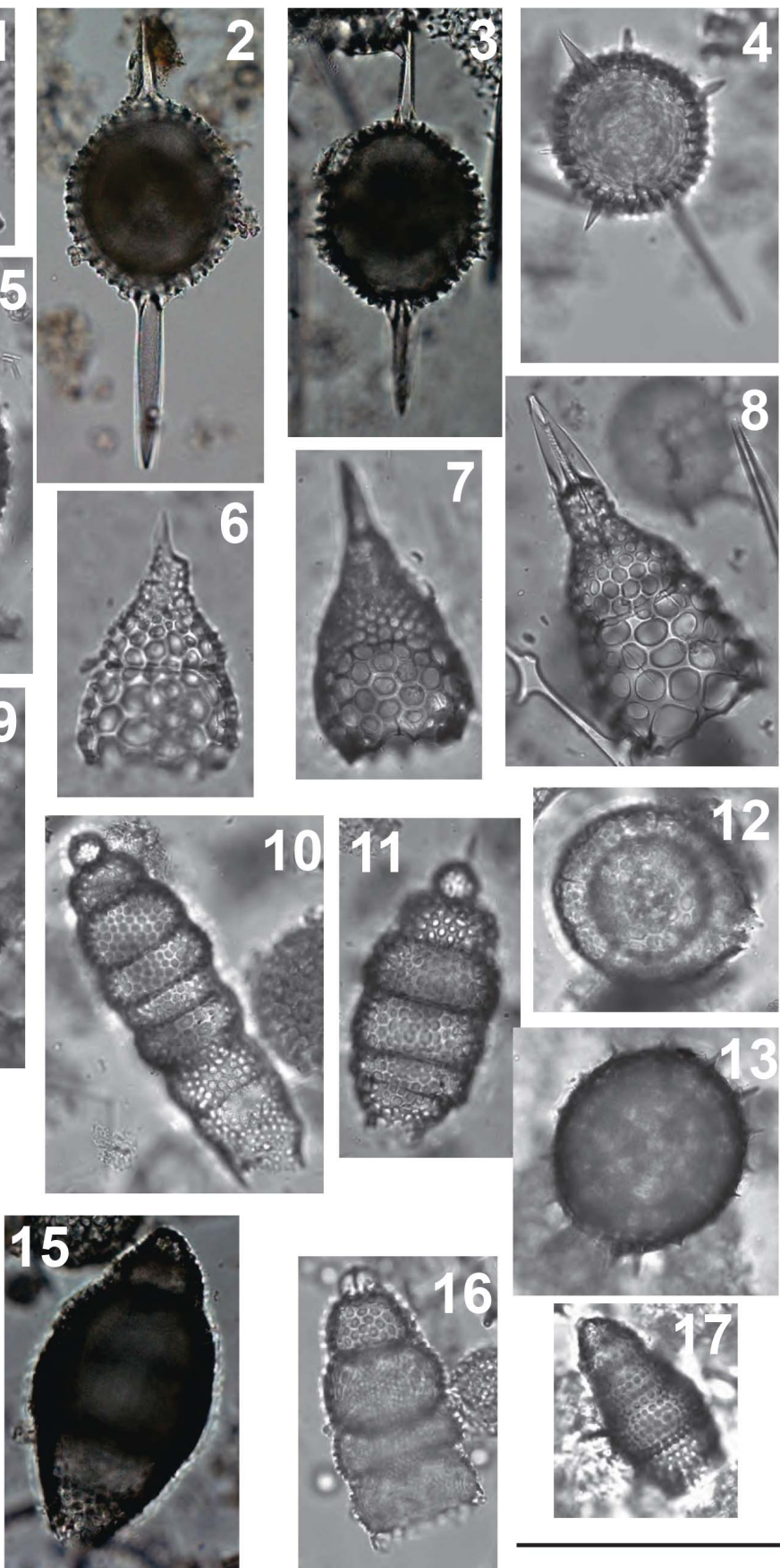
Plate P1 (continued). Radiolarians, Hole U1371D. Scale bar $=50 \mu \mathrm{m}$. 18. Eucyrtidium calvertense. 19. Didymocyrtis penultima. 20. Didymocyrtis laticonus. 21. Eucyrtidium inflatum. 22. Triceraspyiris antarctica. 23. Cycladophora davisiana. 24. Prunopyle titan. 25. Triceraspyris coronata. 26. Acrosphaera australis. 27. Antarctissa cylindrica. 28. Lychnocanoma grande. 29. Cycladophora pliocenica. 30. Acrosphaera labrata. 31-33. Dendrospyris megalocephalis. 34. Antarctissa deflandrei. (18, 23, 27) Sample 329-U1371D-4H-6, 18-20 cm; $(19,30)$ Sample 329U1371D-10H-5, 100-102 cm; (20, 28, 29) Sample 329-U1371D-11H-5, 100-102 cm; (21) Sample 329-U1371D11H-1, 100-102 cm; (22, 26, 31) Sample 329-U1371D-11H-2, 100-102 cm; (24) Sample 329-U1371D-8H-5, 2527 cm; (25, 32, 33) Sample 329-U1371D-11H-3, 100-102 cm; (34) Sample 329-U1371D-11H-4, 100-102 cm.
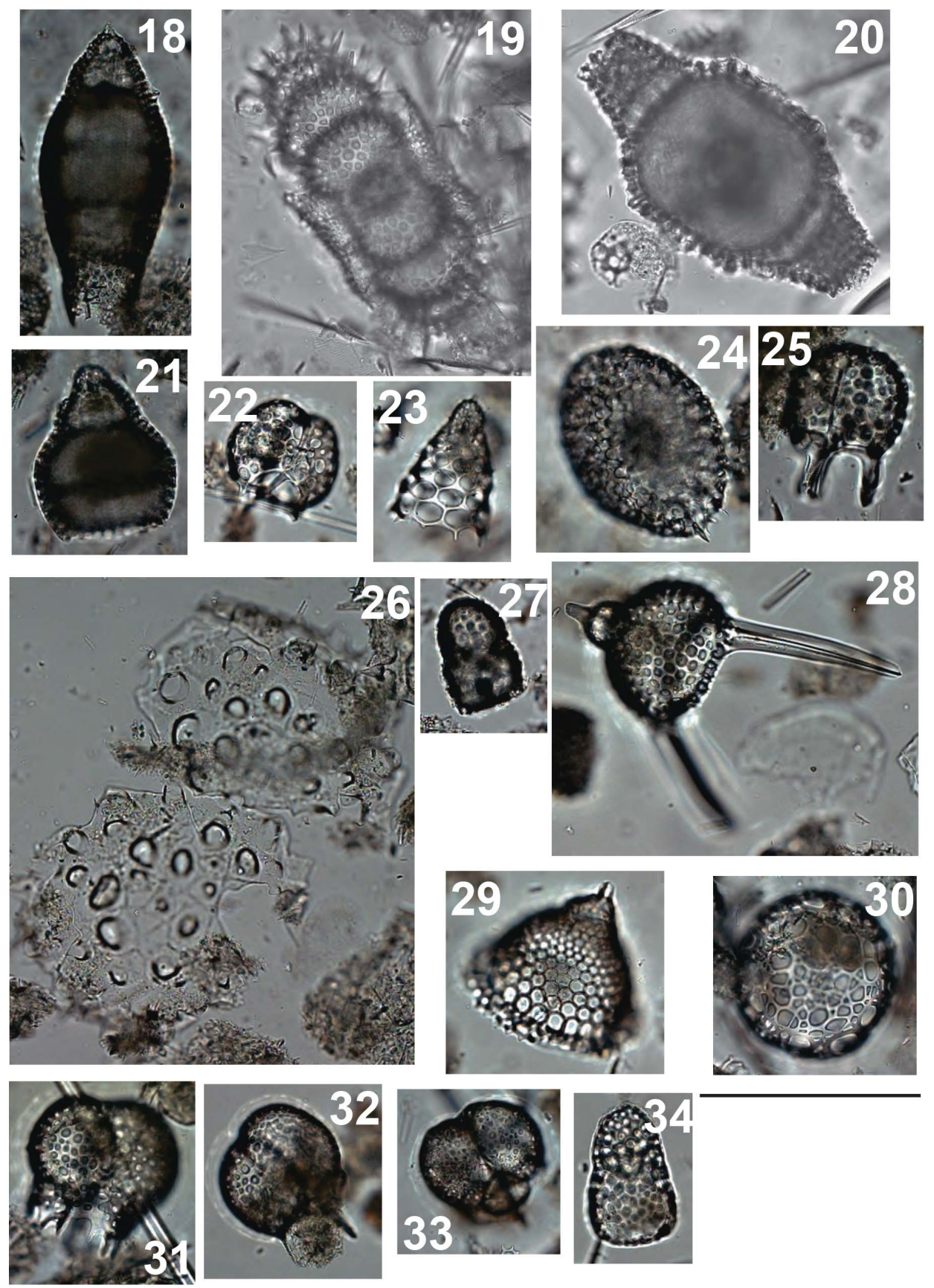